\title{
Seminiferous Epithelium Cycle in Bombina orientalis
}

\author{
Min-Joo Yi ${ }^{1}$ and ${ }^{\dagger}$ Jung-Hun Lee ${ }^{2}$ \\ ${ }^{1}$ Graduate School of Education, Kyungnam University, Changwon 631-701, Korea \\ ${ }^{2}$ Dept. of Science Education, Kyungnam University, Changwon 631-701, Korea
}

\begin{abstract}
The purpose of the present study was to examine the seminiferous epithelium cycle of Bombina orientalis using a light microscope. The cycle was divided into a total of 10 stages, according to the morphological characteristics of the cells. The spermatogenetic cells included primary spermatogonia, secondary spermatogonia, primary spermatocytes, secondary spermatocytes, spermatid and sperm. At stage I, the primary spermatogonia was located closer to basal lamina of the seminiferous tubule without spermatocyst formations. Especially at the stage II, the secondary spermatogonia were located in the spermatocyst. The primary and secondary spermatocytes were found from stages III to VI. The secondary spermatocytes were smaller in size than the primary spermatocytes, but they had thicker nucleoplasm and smaller nuclei. The round-shaped, early sperm cells were formed in stage VII, and further divided at stage VIII to have more concentrated nucleoplasm before division to matured sperm cells. At stage $\mathrm{X}$, the matured sperm cells emerged from the spermatocyst. Considering the above results, this study presented the special characteristics in the generation and type of sperm formation. The germ cell formation occurred in various stages, like the perspectives of Franca et al (1999), ultimately, providing taxonomically useful information.
\end{abstract}

Key words : Bombina orientalis, Spermatogenesis, Seminiferous epithelium cycle, Spermatocyst

\section{INTRODUCTION}

The class Amphibia contains vertebrate animals that typically live on land, originally evolved from a form between a fish and a reptile which spread throughout the world (Green \& Sessions, 1991; Maxson, 1992; Zug, 1993). Taxonomically, it is classified into about 4,500 different species under 4 orders: Gymnophiona, Meantes, Caudata and Anura (Goin et al., 1978; Duellman \& Trueb, 1986; Maxson, 1992; Duellman, 1993; Zug, 1993)

Spermatogenesis refers to a periodic process involving a series of somatic cell and metotic divisions, along with complicated cell maturation and differentiation for the production of haploid cells from polyploid cells (Franca et al., 1999; Weinbauer \& Wessels, 1999; Lee \& Mōri, 2004) Therefore, such cycles include a series of complete, highly structured and successful cellular associations in a particular given area of the seminiferous tubule, for which the productive system is comprises of multiple stages (Leblond \& Clermont, 1952; Clermont, 1972; van Haaster \& de Rooij, 1993; Franca et al., 1999; Mizukami et al., 2001; Paula et al., 1999).

Spermatogenesis in amphibians is controlled by external factors, including endogenous rhythm, photoperiod, habitat,

\footnotetext{
Manuscript received 5 December 2014, Received in revised form 20 December 2014, Accepted 3 February 2015

$\dagger$ Corresponding Author : Jung-Hun Lee, Dept. of Science Education, Kyungnam University, 449 Woryeong-dong Masanhappo-gu, Changwon-si, Gyeongsangnam-do, 631-701, Korea. Tel. : +82-55-249-2243, Fax : +82-55-999-2150, E-mail : jhlee@kyungnam.ac.kr

This is an Open Access article distributed under the terms of the Creative Commons Attribution Non-Commercial License (http:// creativecommons.org/licenses/by-nc/3.0) which permits unrestricted non-commercial use, distribution, and reproduction in any medium, provided the original work is properly cited.
} 
etc. (Paniagua et al., 1990), which can vary according to the weather (Cobellis et al., 2002; Chieffi \& Minucci, 2004). Studies on external factors such as temperature and photoperiod are on-going, with examination of amphibian reproduction in an environment customized to each species around the summer season (Rastogi et al., 1976; Pierantoni et al., 1984; Paniagua. 1990; Pudney. 1995).

Amphibians form sperm especially at the beginning of the breading season (Chieffi et al., 2000). Breeding takes place from early spring to late summer. The favored conditions for embryonic development (Ko et al., 1998) and the optimal external factors, such as temperature, photoperiod, water level, etc., vary according to species; therefore, each species has a different set of favorable conditions for breeding (Denver, 1998).

After emerging from hibernation, the testicular cells in amphibians are controlled by hormone or cellular signal delivery systems, stimulated by change of the external environment (Lecouteux et al., 1985; Varriale et al., 1986; Bremner et al., 1994). Around breeding season, the primordial germ cell, type A spermatogonia, initiates reproduction (Raucci \& Di Fiore, 2007) and then completes sperm formation prior to hibernation (Ko et al., 1998). Therefore, the formation of amphibians sperm is highly dependent on the climate conditions of the habitat and species. Ultimately, observation of the structural changes in the testis via cellular analysis is required, particularly focusing on the division of reproductive cells upon testicular division (Kera \& Iwasawa, 1981; Yoneyama \& Iwasawa, 1985).

In amphibian, the testis is divided into the seminiferous lobule and interlobular tissue. In the seminiferous lobule, germ cell cysts are formed by the gathering of germ cells in the same division stage, wherein the production and division of germ cells takes place. Each germ cell cyst is composed of germ cells at a specific division stage (Pudney, 1995). The mature sperm in the cyst is then discharged to the lumen through spermiation (Grier, 1992). The classifi- cation of phase of seminiferous epithelium in the sperm formation process becomes a useful tool to study the various factors affecting the regeneration of the spermatogonium, as well as for analysis of the structural and cellular development, and the division of reproductive cells (Clemont, 1972). In addition, the generation and type of sperm formation, along with the formation of reproductive cells occurs in various stages depending on the species, which provides taxonomically useful information (Franca et al., 1999). Stage division of the seminiferous epithelium has been performed on numerous mammals so far, whereas the studies on anurans were performed on Rana esculenta (Rastogi et al., 1976), Rana catesbeiana (Yoneyama \& Iwasawa, 1985; Go \& Lee, 2001), Bufo japonicus formosus (Moriguchi \& Iwasawa, 1987) and $R$. perezi (Delgado et al., 1989). Therefore, this study was performed to investigate the division stage of reproductive cell through the seminiferous epithelium cycle in Bombina orientalis and further investigate its differentiation from other anural amphibian type.

\section{MATERIALS AND METHODS}

Five male Bombina orientalis collected from April to May 2012 near Hwawangsan, located in Changnyeong, Gyeongnam, Korea, were used in this study. The subjects were transferred to the laboratory immediately after collection, and then anesthetized with ethyl ether for extraction of the testis. The extracted testis was deposited in a small closed container containing an aqueous solution of 3\%-Glutaraldehyde $\left(4^{\circ} \mathrm{C}, \mathrm{pH} 7.4\right.$, Millong's buffer) at $4^{\circ} \mathrm{C}$ for about 2 hours. The testicular tissue was then cut to the thickness of $1 \sim 1.5$ $\mathrm{mm}^{3}$ and then pre-fixed in an aqueous solution of $3 \%$ Glutaraldehyde $\left(4^{\circ} \mathrm{C}, \mathrm{pH} 7.4\right.$, Millong's buffer $)$ again. The pre-fixed tissues were washed in a buffer solution $\left(4^{\circ} \mathrm{C}, \mathrm{pH}\right.$ 7.4, Millong's buffer) 3 times. After washing, post-fixation was carried out with $1.33 \%-\mathrm{OsO}_{4}$ ( $\mathrm{pH} 7.4$, Millong's buffer) 
for 2 hours, after which they were washed with the same buffer solution as prior to the dehydration at increasing ethanol concentrations (from 70 to $100 \%$ ). The dehydrated tissues were embedded in Epon 812 mixed solution. An ultramicrotome (MT-6000, Sorvall, Dupont) was used on the embedded tissues to obtain serial sections of $400 \mathrm{~nm}$, which were then dyed with $0.5 \%$-toluidine blue. Each serial stage of the seminiferous epithelium was observed under an optical microscope.

\section{RESULTS}

The division stage of the seminiferous epithelium in
Bombina orientalis were based upon the cellular morphological characteristics, with division into a total of 10 stages. Cellular division was observed in the following order: from primary spermatogonia to secondary spermatogonia, primary spermatocytes, secondary spermatocytes, spermatids and sperm. Germ cell cysts at the same stage were attached to the seminiferous epithelium, and the sperms which fell out from the germ cell cyst were discharged into the inner seminiferous tubule (Table 1, Figs 1-10).

\section{Stage I}

Both primary spermatogonia (Psg) and secondary sper-

Table 1. Comparison of differentiation stage of the seminiferous tubules in 5 species of Anurans

\begin{tabular}{|c|c|c|c|c|c|c|c|c|c|c|c|c|}
\hline Cell typ & Stage & I & II & IIII & IV & V & VI & VII & VIII & IX & X & Authors \\
\hline \multirow{16}{*}{$\mathrm{SCG}$} & \multirow{4}{*}{ Psg } & & & & & & & & & & & (1), (3) \\
\hline & & & & & & & & & & & & (2) \\
\hline & & & & & & & & & & & & (4) \\
\hline & & & & & & & & & & & & + \\
\hline & \multirow{4}{*}{ Ssg } & & & & & & & & & & & (1), (2) \\
\hline & & & & & & & & & & & & (3) \\
\hline & & & & & & & & & & & & (4) \\
\hline & & & & & & & & & & & & + \\
\hline & \multirow{4}{*}{ Psc } & & & & & & & & & & & (1), (3) \\
\hline & & & & & & & & & & & & (2) \\
\hline & & & & & & & & & & & & (4) \\
\hline & & & & & & & & & & & & + \\
\hline & \multirow{4}{*}{ Ssc } & & & & & & & & & & & (1), (3) \\
\hline & & & & & & & & & & & & (2) \\
\hline & & & & & & & & & & & & (4) \\
\hline & & & & & & & & & & & & + \\
\hline \multirow{3}{*}{ SMG } & \multirow{3}{*}{ St } & & & & & & & & & & & $(1),(2),(3)$ \\
\hline & & & & & & & & & & & & (4) \\
\hline & & & & & & & & & & & & + \\
\hline
\end{tabular}

Psc, primary spermatogonia; Psg, primary spermatogonia; SCG, spermatocytogenesis; SMG, spermiogenesis; Ssc, secondary spermatocytes; Ssg, secondary spermatogonia: St, spermatid. (1), Rana rugosa (Ko, 1997a); (2), Rana nigromaculata (Ko, 1997b); (3), Rana coreana (Shin \& Ko, 2014); (4), Rana catosbeiana (Go \& Lee, 2001); ${ }^{\dagger}$, Bombina orientalis (Present studies). 


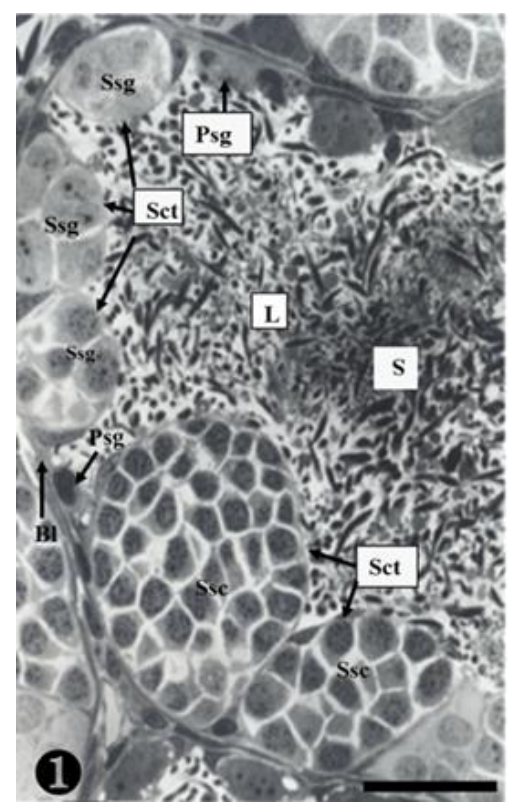

Fig. 1. Stage I shows primary spermatogonia (Psg), secondary spermatogonia (Ssg), secondary spermatocytes (Ssc) and sperm (S) of B. orientalis. The primary spermatogonia did not form spermatocyst. Bl, basal lamina; L, lumen; Sct, spematocyst. Scale bar $=30 \mu \mathrm{m}$.

matogonia ( $\mathrm{Ssg}$ ) were located near the seminiferous basal lamina (Bl), and numerous sperm (S) were observed in the lumen $(\mathrm{L})$ of the seminiferous tubule. The primary spermatogonia in this cycle did not form spermatocysts (Sct) (Fig. 1).

\section{Stage II}

Many secondary spermatogonia (Ssg) were found in spermatocysts (Sct), around which many Sertoil cells (Sc) were found. Numerous spermatids were located around the spermatocyst (Sct) and the lumen (L), and the interstitial cells (Ic) between the seminiferous tubules were observed (Fig. 2).

\section{Stage III}

The primary spermatogonia (Psg) were spread near the basal lamina (Bl) and many primary spermatocytes (Psc) were found in the spermatocyst (Sct). These spermatocytes

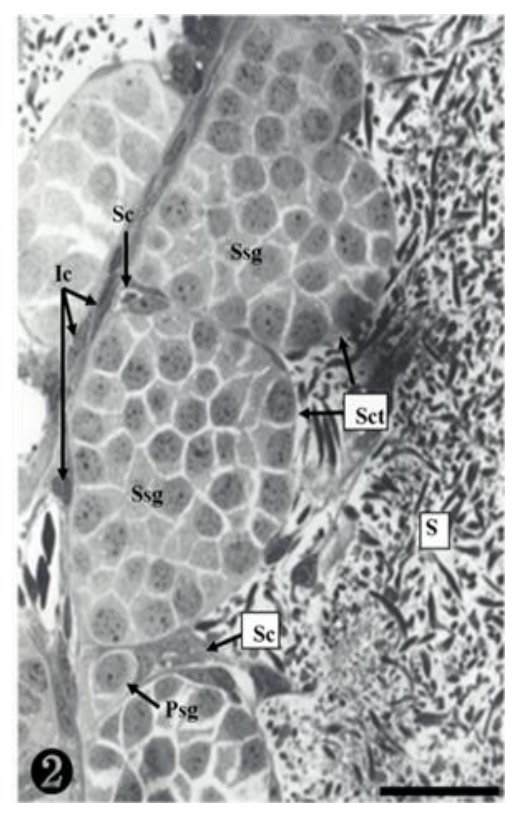

Fig. 2. Stage II presents primary spermatogonia (Psg), secondary spermatogonia (scg) and sperm (S). Note that the secondary spermatogonia were located in the spermatocyst. Ic, interstitial cell; Sc, Sertoli cell; Sct, spematocyst. Scale bar $=30 \mu \mathrm{m}$.

showed somewhat different concentrations of nucleoplasm, due to the differences of serial cellular division. The cellular size of the secondary spermatocytes (Ssc) in the spermatocyst was smaller than that of the primary spermatocytes, but their chromatin was much thicker, whereas the nucleus was smaller. Tremendous amounts of sperms (S) were observed near the spermatocyst (Fig. 3).

\section{Stage IV}

As shown in the above stages, the primary spermatogonia were located near the basal lamina, and primary and secondary spermatocytes were observed in the spermatocyst. Spermatocysts where numerous primary spermatogonia were observed were located in the inner space adjacency far away from the basal lamina. The nucleoplasm was much more concentrated than in stage III. The size of the secondary spermatocytes was smaller than that of the primary spermatocytes, In addition, their chromatin was much thicker, whereas the nucleus was smaller (Fig. 4). 


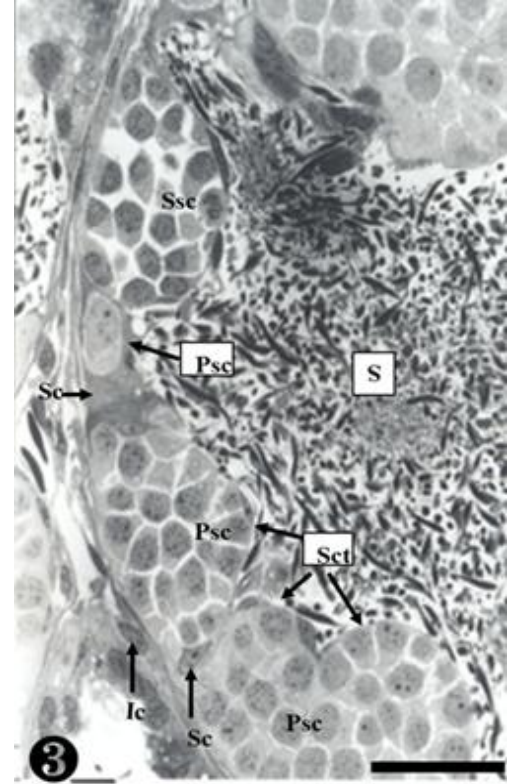

Fig. 3. Stage III contains primary spermatogonia (Psg), primary spermatocytes (Psc), secondary spermatocytes (Ssc) and sperm (S). B1, basal lamina; Ic, interstitial cell; Sc, Sertoli cell; Sct, spematocyst. Scale bar $=30 \mu \mathrm{m}$.

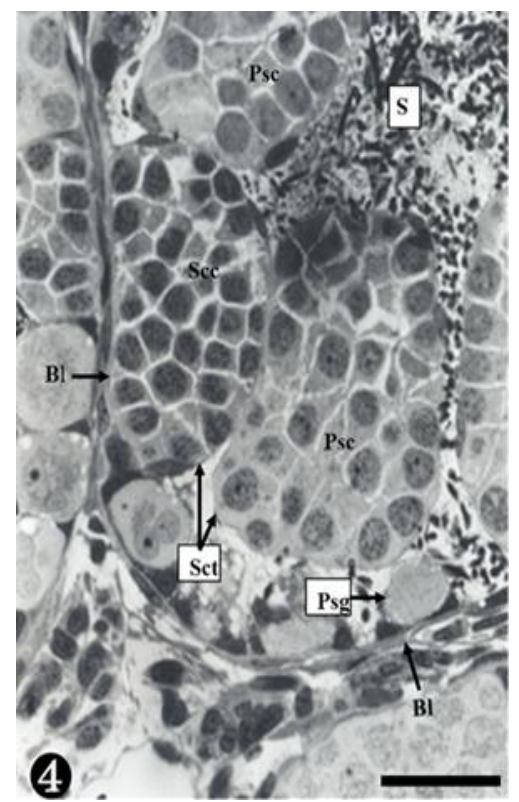

Fig. 4. Stage IV shows primary spermatogonia (Psg), primary spermatocytes (Psc), secondary spermatocytes (Ssc) and sperm (S). B1, basal lamina; Sct, spematocyst. Scale bar $=30 \mu \mathrm{m}$.

\section{Stage V}

A group of secondary spermatocytes was created, located in the spermatocyst. In addition, Sertoli cells were observed around the spermatocysts (Fig. 5).

\section{Stage VI}

Secondary spermatocytes were observed in the spermatocys, and the spermatocysts composed of primary spermatocytes showed different concentrations of nucleoplasm due to differrences in the serial cellular division (Fig. 6).

\section{Stage VII}

At this stage, the secondary spermatocytes were much more divided, creating spermatids in the maturing process. They were also found in the spermatocyst (Fig. 7).

\section{Stage VIII}

The nucleoplasm of the sperm cells near the basal lamina was observed to be much more concentrated, and

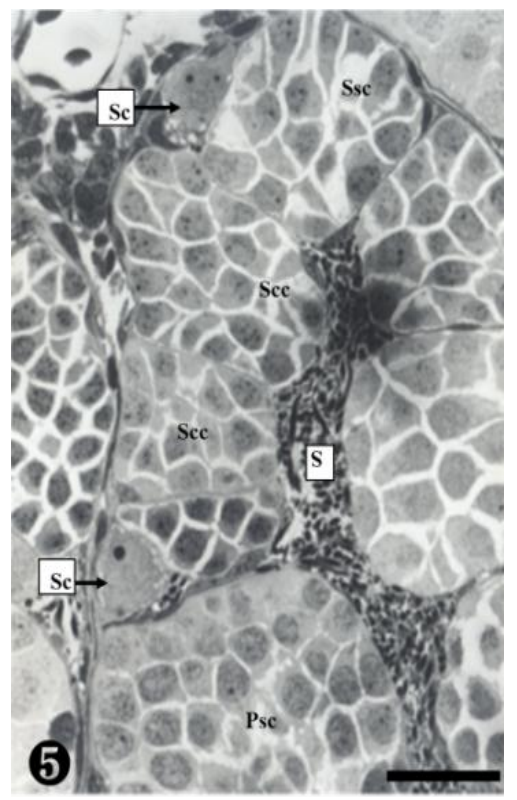

Fig. 5. Stage V contains primary spermatocytes (Psc), and secondary spermatocytes (Ssc) and sperm (S). Bl, basal lamina; Sc, Sertoli cell. Scale bar $=30 \mu \mathrm{m}$. 


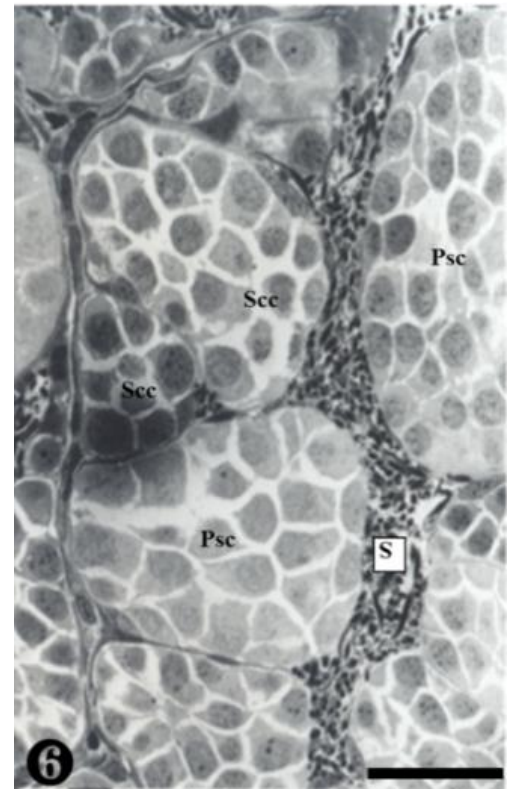

Fig. 6. Stage VI presents primary spermatocytes (Psc), secondary spermatocytes (Ssc) and sperm (S). Scale bar $=30 \mu \mathrm{m}$.

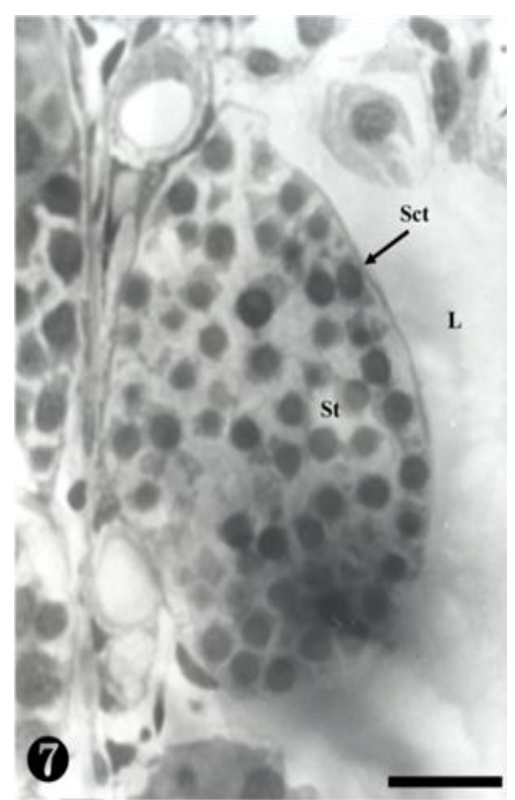

Fig. 7. Stage VII shows early round spermatid (St). L, lumen; Sct, spermatocyst. Scale bar $=20 \mu \mathrm{m}$.

some matured sperm cells were also observed. They were still located in the spermatocyst (Fig. 8).

\section{Stage IX}

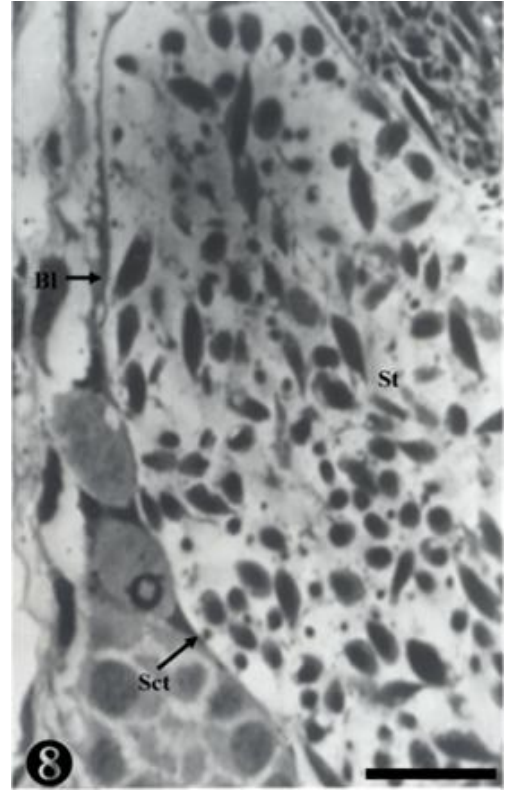

Fig. 8. Stage VIII shows maturating spermatids (St). Bl, basal lamina; Sct, spermatocyst. Scale bar $=20 \mu \mathrm{m}$.

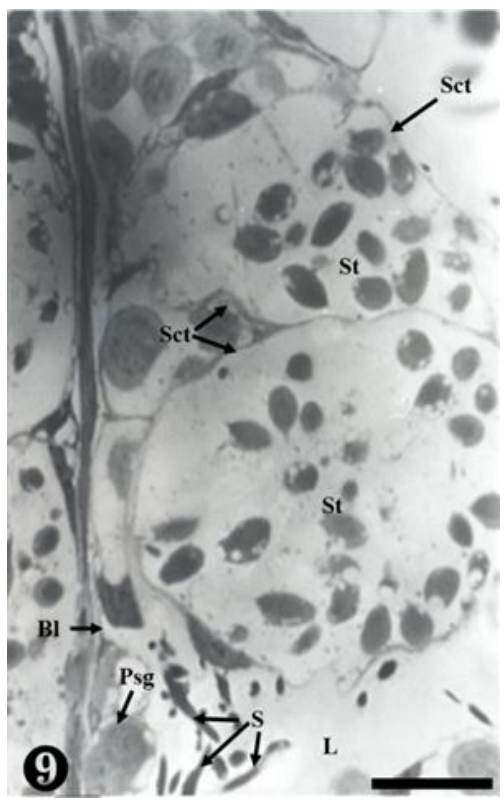

Fig. 9. Stage IX shows primary spermatogonis (Psg), elongating spermatids $(\mathbf{S t})$, and $\operatorname{sperm}(\mathbf{S}) . \mathrm{Bl}$, basal lamina; L, lumen; Sct, spermatocyst. Scale bar $=30 \mu \mathrm{m}$.

The primary spermatogonia were located in the basal lamina, whereas the matured sperm were detached, remaining in the inner seminiferous tubule. Some sperm were observed in small and large spermatocysts, while 
some were observed on the wall-side of the spermatocyst (Fig. 9).

\section{Stage $X$}

Degenerating spermatogonia (Dpsg) were found near the basal lamina, whereas the matured sperms were detached; therefore, the cyst was found to be almost empty. The inner seminiferous tubules were filled with countless sperm (Fig. 10).

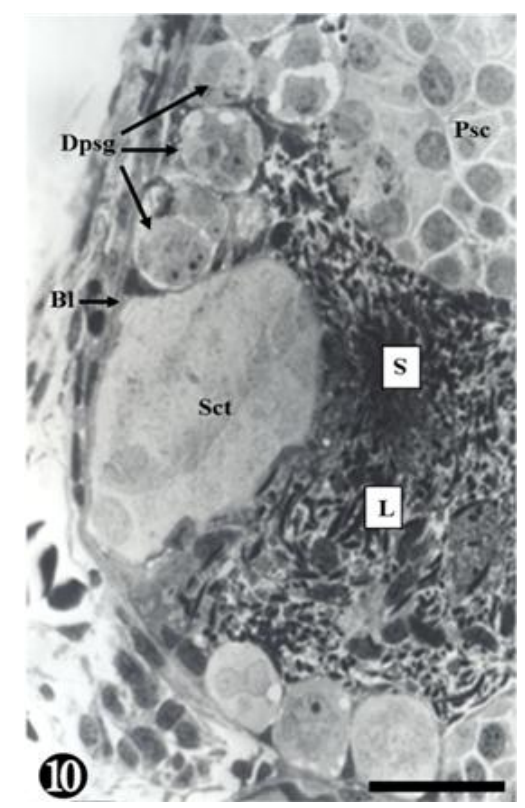

Fig. 10. Stage $X$ presents maturated sperm (S). Bl, basal lamina; L, lumen. Scale bar $=30 \mu \mathrm{m}$.

\section{DISCUSSION}

Amphibian spermatogenesis includes germ cell cysts and seminiferous lobules. Meiosis is started by the division of the primary spermatocytes. In this step of the sperm formation process, the reproductive cells divided from the primary spermatogonia in the seminiferous tubule create a single cyst once they become secondary spermatogonia. Each germ cell cyst is filled with reproductive cells at the same division stage, which are to be divided simultaneously within the cyst. The division of reproductive cells, therefore, depends on the environmental conditions in the habitat (van Tienhoven, 1983).

In this study, the division of reproductive cells in Bombina orientalis was divided into primary spermatogonia, secondary spermatogonia, primary spermatocytes, secondary spermatocytes, spermatids and sperm, just like the stages proposed by Burgos \& Fawcett (1956). In addition, the seminiferous epithelium cycle was divided into a total of 10 stages, according to the cellular maturation process and the morphological characteristics. The nucleoplasm became more concentrated from the primary spermatocytes to the secondary spermatocytes, while the size of the cell became smaller. In contrast, the nucleoplasm of the maturing germ cell became more concentrated than the germ cell at the earlier stages, whereas the nucleus and cytoplasm grew more. The spermatocysts were not created in the primary spermatogonia, but was directly attached to the seminiferous lobule, being independent from other germ cell cysts. Spermatids were created from the secondary spermatocytes and remained in the spermatocyst, from which they later emerged after becoming fully matured. In other words, spermiation occurred and the cyst, composed of mature sperm, was disassembled, discharging into the inner seminiferous lobule (Pierantoni et al., 2002).

The seminiferous tubule lumen were not created, and the process was explained by 4 stages: the seminiferous tubule was created in the early sperm formation stage (Stage I) where only small sperms remained; the lumen of the seminiferous tubule were created and numerous sperms remained but did not move to the lumen in the later sperm formation stage (Stage II); the matured sperms moved to the seminiferous tubule lumen (Stage III); and the sperms and primary spermatogonia remained in the seminiferous tubules after the discharge of sperm (Stage IV) (Nagahama, 1986). In contrast, Bombina orientalis underwent maturation in the spermatocyst, from which the matured sperms fell out (Ko, 1997a, 1997b; Shin \& Ko, 2014). This study pre- 
sented the same results. However, R. catosbeiana showed an 8-stage seminiferous epithelium cycle, which is 2stages faster than Bombina orientalis (Fig. 1). In other words, like $B$. orientalis, the sperm of $R$. catosbeiana matured in the spermatocyst without creating seminiferous tubule lumen, and then the mature sperms fell out (Go \& Lee, 2001). Emergence of the matured sperms from the spermatocyst to the lumen was caused by degradation of the epithelial cyst surrounding the germ cell cyst, whereas the epithelial lining of the seminiferous lobule was located near the germ cell cyst at various division stages. Each cell cyst was filled with germ cells at the same division stage, therefore, division in the cyst occurred concurrently. This aspect is considered a special trait of Amphibians that cannot be found in mammals.

The spermatocysts were formed by the protrusion of Sertoli cells, according to Sprando \& Russell (1988), whereas Burgos \& Fawcett (1956) claimed that they were formed by the follicular cells at the division stage of germ cells. Burgos \& Fawcett (1956) claimed that Bufo arenarum, the toad, differing from other frog classes, formed the spermatocyst at the primary spermatogonia. Considering the previous studies and the results of this study, focused on Bombina orientalis, it seems that spermatocysts composed of germ cells at the same division stage are formed, which show differences in the spermatocyte according to the species under the same class, even if the formation period of the spermatocyst is the same.

\section{CONFLICT OF INTEREST}

The authors reported no potential conflicts of interest.

\section{REFERENCES}

Bremner WJ, Millar MR, Sharpe RM, Saunders PT (1994) Immunohistochemical localization of androgen receptors in the rat testis: Evidence for stage dependent expression and regulation by androgens. Endocrinol 135: 1227-1234.

Burgos MH, Fawcett DW (1956) An electron microscope study of spermatid differentiation in the Toad, Bufo arenarum. Hensel J Biophysic Biochem Cyto 2:223253.

Chieffi P, Colucci-D'Amato GL, Staibano S, Franco R, Tramontano D (2000) Estradiol-induced mitogen-activated protein kinase (extracellular signal regulated kinase 1 and 2) activity in the frog (Rana esculenta) testis. J Endocrinol 167:7-84.

Chieffi P, Minucci S (2004) Environmental influence on testicular MAP kinase (ERK1) activity in the frog, Rana esculenta. J Exp Biol 207:2209-13.

Clermont Y (1972) Kinetics of spermatogenesis in mammals: seminiferous epithelium cycle and spermatogonial renewal. Physiol Rev 52:198-236.

Cobellis G, Meccariello R, Fienga G, Pierantoni R, Fasano $S$ (2002) Cytoplasmic and nuclear fog protein forms regulate resumption of spermatogenesis in the frog, Rana esculenta. Endocrinol 143:163-170.

Delgado MJ, Gutierrez PP, Alonso Bedate M (1989) Seasonal cycle in testicular activity in the frog, Rana perezi. Gen Com Endocrinol 73:1-11.

Denver RJ (1998) Hormonal correlates of environmentally induced metamorphosis in the western spadefoot toad, Scaphiopus hammondii. Gen Comp Endocrinol 110: 326-336.

Duellman WE (1993) Amphibian species of the world: Additions and corrections. Mus Nat Hist Univ Kansas special publ. 21:13.

Duellman WE, Trueb L (1986) Biology of Amphibians. McGraw-Hill. New York. pp. 670.

Franca LR, Becker-Silva SC, Chiarini-Garcia H (1999) The length of the cycle of seminiferous epithelium in goat (Capra hircus). Tissue and Cell 31:274-280. 
Go SH, Lee JH (2001) Differentiation of seminiferous epithelium and spermiogenesis in the testis of Rana catesbeiana. Korean J Electr Micros 31:134-156.

Goin CJ, Goin OB, Zug GR (1978) Introduction to Herpetology (3rd ed). W. H. Freeman and Company. San Francisco. pp. 378.

Green DM, Sessions SK (1991) Amphibian Cytogenetics and Evolution. Academic Press. San Diego. pp. 456.

Grier HJ (1992) Chordate testis: the extracellular matrix hypothesis. J Exp Zool 261:151-160.

Kera Y, Iwasawa H (1981) Functional histology of the testis in the process of sexual maturation in the frog, Rana nigromaculata. Zool Mag 90:6-14.

Ko SK (1997a) Studies on the reproductive cycle in Rana rugosa. J Indust Technol 18:539-549.

Ko SK (1997b) Studies on the reproductive cycle in Rana nigromaculata. J Indust Technol 4:269-277.

Ko SK, Kang HM, Im WB, Kwon HB (1998) Testicular cycles in three species of Korean frogs: Rana nigromaculata, Rana rugosa, and Rana dybowskii. Gen Comp Endocrinol 111:347-358.

Leblond CP, Clermont Y (1952) Definition of the stages of the cycle of the seminiferous epithelium in the rat. Annals of the New York Academy of Sciences 55:548573.

Lecouteux A, Garnier DH, Bassez T, Joly J (1985) Seasonal variations of androgens, estrogens, and progesterone in the different lobules of the testis and in the plasma of Salamandra salamandra. Gen Comp Endocrinol 58: 211-221.

Lee JH, Mōri T (2004) Annual cycle of the seminiferous epithelium of Myotis macrodactylus. J Fac Agr Kyushu Univ 49:355-365.

Maxson LR (1992) Tempo and pattern in anuran speciation and phylogeny: An albumin perspective. In: Adler K (ed). Herpetology: Current Research on Amphibians and Reptiles. Society for the study of Amphibians and Reptiles. pp. 41-57.

Mizukami T, Kuwahara S, Ohmura M, Linuma Y, Izumikubo J, Hagiwara M, Kurohmaru M, Hayashi Y (2001) The cycle of the seminiferous epithelium in the greater Japanese shrew mole, Urotrichus talpoides. J Vet Med Sci 63:31-35.

Moriguch Y, Iwasawa H (1987) Annual change in male reproductive organs in Bufo japonicus formosus: Histological observation. Gen Endocrinol 6:115-120.

Nagahama Y (1986) Vertebrate Endocrinology. Academic Press. New York. pp. 339-437.

Paniagua R, Fraile B, Saez FJ (1990) Effects of photoperiod and temperature on testicular function in amphibians. Histol Histopathol 5:356-378.

Paula TAR, Chiarini-Garcia H, Franca LR (1999) Seminiferous epithelium cycle and it's duration in capybaras (Hydrochoerus hydrochaeris). Tissue and Cell 31:327-334.

Pierantoni R, Cobellis G, Meccariello R, Palmiero C, Fienga G, Minucci S, Fasano S (2002) The amphibian testis as model to study germ cell progression during spermatogenesis. Comp Biochem Physiol Biochem Mo1 Biol 132:131-139.

Pierantoni R, Iela L, D'istria M, Fasano S, Rastogi RK, Delrio G (1984) Seasonal testosterone profile and testicular responsiveness to pituitary factors and gonadotrophin releasing hormone during two different phases of the sexual cycle of the frog (Rana esculenta). J Endocrinol 102:387-392.

Pudhey J (1995) Spermatogenesis in nonmammalian vertebrates. Microsc Res Tech 32:459-497.

Rastogi RK, Iela L, Saxena PK, Chieffi G (1976) The control of spermatogenesis of the green frog, Rana esculenta. J Exp Zool 196:151-166.

Raucci F, Di Fiore MM (2007) The c-kit receptor protein in the testis of green frog Rana esculenta: seasonal changes in relationship to testosterone titres and spermatogonial proliferation. Reprod 133:51-60. 
Shin JM, Ko SK (2014) A study on the testicular cycle of Korean brown forg (Rana coreana). Korean J Environ Biol 32:153-158.

Sprando RL, Russell LD (1988) Spermiogenesis in the bullfrog (Rana catesbeiana): A study of cytoplasmic events including cell volume changes and cytoplasmic elimination. J Morph 198:303-319.

van Haaster LH, de Rooij DG (1993) Cycle of the seminiferous epithelium in the djungarian hamster (Phodopus sungorus sungorus). Biol Reprod 48:515-521.

van Tienhoven A (1983) Reproductive Physiology of Vertebrates. Second Edition. Cornell University Press. New York. pp. 137-169.
Varriale B, Pierantoni R, Di Matteo L, Minucci S, Fasano S, D'Antonio M, Chieffi G (1986) Plasma and testicular estradiol and plasma androgen profile in the male frog Rana esculenta during the annul cycle. Gen Comp Endorcrinol 64:401-404.

Weinbauer GF, Wessels J (1999) 'Paracrine' control of spermatogenesis. Andrologia 31:249-262.

Yoneyama H, Iwasawa H (1985) Annual changes in the testis and accessary sex organs of the Bullfrog, Rana catesbeiana. Zool Sci 2:229-237.

Zug GR (1993) Herpetology: An Introductory Biology of Amphibians and Reptiles. Academic Press. San Diego. pp. 527. 